\title{
Benefits and Difficulties of the National Service Training Program in Rizal Technological University
}

\author{
Leonila C. Crisostomo*, Ma. Teresa G. Generales, Amelita L. De Guzman
}

Research and Development Center, Rizal Technological University, Philippines

"crisostomoleonila@yahoo.com

Keywords: Nation building, national security, civic welfare, proper hygiene, values formation

\begin{abstract}
The primary purpose of this study is to ascertain the benefits of the National Service Training Program (NSTP) implementation and to identify the problems encountered by its implementers. Results showed that the benefits derived from the program were topped by enhancement of skills on basic leadership with emphases on the ability to listen and ability to communicate which were rated very important and very much benefited among other training aspects of the program. Results also revealed that students are aware of the importance of physical, mental and social health as well as the observance of proper hygiene for overall sense of well-being. Although recreation is one aspect that the respondents find important, appreciation of it underscores the need to have more time for assignments and projects as most of the respondents are enrolled in their respective courses with 29 units, making them unable to appreciate the perks of involving themselves into various recreational activities. Problems in the implementation showed lack of provision of materials and equipment and of budgetary allocation which rendered full implementation weak as students and faculty involved in the community immersion have to rely on their own resources, in addition to the indifference and passivity of the local government officials. Based on the findings, the researchers recommended that: the school administrators need to allocate adequate budget for materials and equipment; periodic faculty development trainings and; to look into the passive attitude of the local officials to ensure that implementation NSTP projects will benefit both clients and implementers.
\end{abstract}

\section{Introduction}

In a world where the time it takes to travel, or to bake a potato, or to process a million calculations shrinks inexorably, only one thing has remained constant: change. It is an enduring historical force with noticeable variations through time. It is also pervasive and is taking place in all aspects of society: culture, economy, political system, family, religion and education.

The underlying concept in change is modernity which is linked to the idea of progress. New directions and initiatives are therefore, imperative to reshape goals and reform agenda especially in education. One of the key areas of national life which need to be pursued relentlessly is education and since, people live in a time of rapid change and growth of knowledge, only he who is in a fundamental sense a scholar, that is, a person who continues to learn and inquire - can hope to keep pace, let alone play the role of guide. The country's greatest resource is its people and to educate a child is to save a person and to guarantee a good national future [1].

To keep up with this change, schools have initiated innovations in the curriculum not only in the elementary and secondary levels but in the tertiary level as well. In this context of change brought about by the need to meet societal demands, National Service Training Program (NSTP) Act of 2001 was promulgated.

The National Service Training Program was established for tertiary level students under Republic Act No. 9163, and was approved December 19, 2001. This program was also implemented December 19, 2001. The purpose of this program is to recognize the Youth's vital role in nationbuilding, promote consciousness among youth and develop their physical, moral, spiritual, intellectual and social well-being. It shall inculcate in the youth patriotism, nationalism, and advance their involvement in public and civic affairs. 
In pursuit of these goals, the youth, the most valuable resource of the nation, shall be motivated, trained, organized and mobilized in military training, literacy, civic welfare and or similar endeavors to the service of the nation.

Under RA 9163, it affirmed the prime duty of the government to serve and protect its citizens. In turn, it shall be the responsibility of all citizens to defend the security of the state and in fulfillment thereof, the government may require each citizen to render personal, military or civil service.

This study aims to determine the demographic profile of the respondents, the benefits of the program in terms of implementation, the perception of the benefits, the difference in the benefits as perceived by the respondents, the difficulties of the program in implementation, and the proposed solutions to the encountered problems. Moreover, this study utilizes a descriptive method in a normative survey approach in addition to the causal-comparative design applied to 463 chosen respondents enrolled during the second semester of school year 2014-2015.

\section{The National Service Training Program}

This act shall be known as the National Service Training Program (NSTP) Act of 2001 [2].

It is hereby affirmed the prime duty of the government to serve and protect its citizens. In turn, it shall be the responsibility of all citizens to defend the security of the Senate in fulfillment thereof; the government may require each citizen to render personal, military or civil service.

In pursuit of these goals, the youth, the most valuable resource of the nation, shall motivated, trained organized and mobilized in military training, literacy, civic welfare and or similar endeavors to the service of the nation.

There is hereby established a National Service Training Program (NSTP), which shall form part of the curricula of all baccalaureate degree courses of at least two (2) year technical-vocational courses and is a requisite for graduation, consisting of the following components:

1. The Reserve Officers' Training Corps (ROTC) which is hereby made optional and voluntary upon the effectivity of this Act;

2. The Literacy Training Service and;

3. The Civic Welfare Training Service

The ROTC under the NSTP shall instill patriotism, moral, virtues, respect for rights of civilian and adherence to the Constitution, among others. Citizenship training shall be given emphasis in all three (3) program components.

The Commission on Higher Education (CHED) and Technical Education and Skills Development Authority (TESDA), in consultation with the Department of National Defense (DND), Philippine Association of State Universities and Colleges (PASUC). Coordinating Council of Private Educational Associations of the Philippines (COCOPEA) and other concerned government agencies may design and implement such other program components as may be necessary in consonance with the provisions of this Act.

Students, male and female, of any baccalaureate degree course or at least two (2) year technical - vocational courses in public and private educational institutional shall be required to complete one (1) of the NSTP components as requisite for graduation.

Each of the aforementioned NSTP program components shall be undertaken for an academic period of two (2) semesters.

In lieu of the two (2) semesters program for any of the NSTP components, a one (1) summer program may be designed, formulated and adopted by the DND, CHED and TESDA.

All higher and technical-vocational institutions, public and private, must offer at least one of the program components. Provided, that State Universities and Colleges shall offer the ROTC component and at least one other component as provided herein: Provided, further, that private higher and technical-vocational education institutions may also offer the ROTC if they have at least three hundred and fifty (350) cadet students.

In offering NSTP whether during the semestral or summer periods, clustering of students from different educational institutions maybe done, taking into account logistics, branch of service 
and geographical considerations. Schools that do not meet the required number of students to maintain the optional ROTC and any of the NSTP components shall allow their students to crossenroll to other schools are being administered by the same or another branch of service of the Armed Forces of the Philippines (AFP), CHED and TESDA to which schools are identified.

Higher and technical-vocational institutions shall not collect any fee for any of the NSTP components except basic tuition fees, which shall not be more than fifty percent $(50 \%)$ of what is currently charged by schools per unit.

In the case of the ROTC, the DND shall formulate and adopt a program of assistance and/or incentive to those students who will take the said component.

The school authorities concerned, CHED and TESDA shall ensure that group insurance for health and accident shall be provided for students enrolled in any of the NSTP components.

According to Sibayan, B., there are implications for literacy and literacy programs of the seven kinds of language literacies. In discussing the question "literate in what language", the importance of the subject in the planning, management and support of literacy programs especially for speakers of languages not used in government and other controlling domains of language.

In the Philippines only Filipino and English are used as media of instruction in the schools. Literacy in these two languages is pursued at the expense of taxpayers' money. School reading materials in two languages are assured.

On the other hand, literacy programs in languages other than English and Filipino are under the sponsorship of non-governmental organizations such as the Summer Institute of Linguistics, the Magbasa Kita Program under the former Senator Santanina Rasul, the Philippine Rural Reconstruction Movement (for adults) and various church groups.

The emphasis on the welfare of the individual as exemplified in such lofty statements as "The child can learn best and faster with the use of his/her native language as medium of instruction" as advocated by some well-meaning, but not well-informed, people is too simplistic and needs serious reexamination in the light of the discussion on "literate in what language?"

There are two sides of the problem (1) many claim, quite correctly, that a great number of Filipinos, especially those in the countryside, will not have much use of English Literacy in the vernacular or in Filipino should be enough. The argument against this reasoning goes this way: (2) In democracy, all citizens should have an equal opportunity to rise and the present language for attaining the "better life" because it is the language for a good education and a good job, its English. The poor should have access to the language that provides for these opportunities.

There is universal agreement that for advanced science and technology, the highest type of literacy in the intellectualized languages of wider communication, especially English, should be secured by the intellectuals and lead populations of the developing countries. The poor but bright children in the country-side should be given the opportunity to learn the language that opens the door to many opportunities.

Value has been defined as any object, activity or frame of mind that a person considers to be very important to his or her life. All our values taken together are called a value system which exists not only on an individual level, but on an organization-wide level as well. Hence, the community where NSTP students assigned could greatly contribute to their values transformation. A corporate culture is a system of values shared throughout any given place or organization.

Values education is founded on a sound philosophy of the human person with all its philosophical ramifications and implications. The supreme and overarching value that characterizes education is HUMAN DIGNITY. Our character and attitudes are formed through the behavior and values formation of those who raised us and those that we adapted or learned from the environment around us. Our relationship with others reflects the kind of values that we have formed throughout our existence and somehow guide us in our decision making processes.

Health is the complete fitness of the body, soundness of mind and wholesomeness of the emotion, which make possible the highest quality of effective living and of service.

First Aid is the skilled application of treatment, using facilities or materials available at the time, that any trained individual gives an ill or injured person while waiting for medical assistance 
to arrive. It is an immediate and temporary care given to a person who suffers from sudden illness or an accident until the doctor arrives.

Recreational activities are socially accepted and socially constructive leisure experience that provides immediate and inherent satisfaction to the individual who voluntarily participates in the activity. It is considered as a pleasurable activity with an aim to relaxation like listening to music and watching television.

Leadership one may use this term to: distinguish people in an organization or group, ability and a relationship [3]. It refers to those who provide direction and guidance. It is an art of inducing subordinates to accomplish their assignments with zeal and confidence [4]. It is the relationship in which one person (the leader) influences others to work together willingly on related tasks to attain goals desired by the leader and or group [5]. Entrepreneurship is capable of generating more jobs, income, goods and services because of the innovative nature of entrepreneurship. This clearly means a better economy and quality living for the people. The welfare of the majority is the primary concern of entrepreneurship, which is their economic development.

Entrepreneurship, according to Professor Nathaniel Left is the capacity of innovation, investment and expansion in new markets, products and techniques [6]. It is the capacity and quality of an individual in effectively and efficiently managing a business towards customer satisfaction and profitability of services. It sees opportunities and makes the best of them. It is putting good use something that otherwise may become wasted [7]. Innovation implies newness, originality and creativity, variation or uniqueness. The innovative person is open to change and does something in a new way [8].

Environmental resource management or natural resource management is the management of natural resources to bring into being the development that is economically viable, socially beneficial, and ecologically sustainable. It refers to the management of natural resources such as land, water, soil, plants and animals, with a particular focus on how management affects the quality of life for both present and future generations [9]. Solid waste management refers to all activities pertaining to the control, transfer and transport, processing and disposal of solid waste in accordance with the best principle of public health, economics, engineering, conservation, aesthetic and other environmental conservation. Its scope includes all attendance administrative, legal planning and engineering function [10].

There is no single solid waste management system method that is universally prescribed and accepted. Every country of community must evolve a system that would suit and be applicable to its needs, economy, location and topography, social culture and resources.

The related literature and studies mentioned will be beneficial to the researchers to support all the findings of the research.

\section{Benefits derived from NSTP-CWTS to its implementers and their ratings of NSTP-CWTS Benefits.}

The respondents of the study considered "ability to communicate" as the number one benefit they derived from NSTP-CWTS implementation with 92.90 percent responses followed by "ability to listen" with 91.80 percent; "involving others in decision making" with 74.90 percent; "better interpersonal relationship" with 69.50 percent; "ability to prioritize others' needs" with 63.10 percent; "knowledge of the key roles of a leader" with 61.10 percent; "ability to be team player" with 55.50 percent and; "ability to empathize" with 41.70 percent.

As to health education, most of the respondents benefited with "awareness of the relationship among physical, mental and social health" with 91.10 percent responses. This was followed by "necessity of observing proper hygiene" with 80.30 percent. Third, was "awareness of the causes and prevention of drug abuse" with 69.80 percent. Fourth was "better understanding of family planning" with 67.20 percent. Next was "wider knowledge of communicable diseases and their prevention", 62.90 percent and the last one was "awareness of laws on drug abuse" with 58.10 percent. 
Three hundred eighty eight or 83.80 percent of the respondents said that they benefited from "enhancement of social skills/interaction with others" of the recreation aspect of NSTP-CWTS. While "better knowledge of using leisure hours productively" scored 73.70 percent followed by "importance of recreation to the different aspects of a person" with 64.10 percent; "knowledge of the kinds of recreation with 63.70 percent; "identify different recreational activities appropriate for different ages" with 62.40 percent and "awareness of recreation for special cases" scored the least with 51.00 percent.

"Better management of waste materials through $3 R$ 's method (reuse, reduce, recycle)" got a score of 86.00 percent while "knowing the importance of environmental cleanliness" got 83.40 percent. "Better knowledge of our country's natural resources" had 67.40 percent. "Ability to identify the causes of ecological imbalance and ways to achieve ecological balance" scored 66.30 percent. The fifth place was "ability to understand human interference with ecosystem" with 65.70 percent. The last was "knowledge of understanding different plants appropriate to quality and type of soil" with 49.70 percent.

Of the six (6) items listed on the aspect of entrepreneurship, the respondents scored the benefits derived as: "better knowledge of the importance of livelihood projects to a person's economic progress" with 74.90 percent. "Advantages and disadvantages of the different forms of business" with 71.10 percent; "Learning simple techniques of doing business" with 70.50 percent; "Better understanding of entrepreneurship with 69.10 percent; "Requirements of organizing a business" with 59.60 percent; and the last "Roles of entrepreneur in our society" with 58.70 percent.

Most of the respondents benefited from the item "Ability to practice different techniques in first aid" of the first aid and emergency aspect of NSTP-CWTS with 86.40 percent. 74.90 percent of them checked "Identify different emergency cases". "Identify and apply survival techniques/procedures during emergency cases" got 74.30 percent. The last was "Observe precautionary measures during emergency cases" with 69.30 percent.

As to values education/formation the respondents scored the items as follows: "Better understanding of the 4M's of good citizen" - 89.40 percent; Actual practice in daily life modern Filipino values" - 87.70 percent; "Identify different Filipino values" - 86.40 percent; Understanding these Filipino values" - 80.30 percent; "Better understanding of nationalism and patriotism" - 76.00 percent; and the last, "Apply appropriate values in every undertaking" - 65.90 percent. highest.

The enumerated benefits were rated by the respondents from a scale of $1-5$, where 5 being the

Findings showed that the respondents rated "Ability to communicate" and "Ability to listen" as very important and very much benefited with mean scores of 4.70 and 4.80 respectively. All other items on basic leadership were rated important with scores ranging from 4.25 to 4.01 .

As to the aspect of health education, "Awareness of relationship among physical, mental and social health" and "Necessity of observing proper hygiene" were rated 4.64 and 4.55 respectively with verbal interpretation as very important and very much benefited. All other items were rated as important and much benefited with mean scores ranging from 4.38 to 4.31 .

All items under the aspect of recreation were rated with mean scores ranging from $4.48-4.19$ verbally interpreted as important.

Mean scores of 4.74 and 4.67 and verbally interpreted as very important and very much benefited degree of benefit; were obtained by "Better management of waste materials through $3 R$ 's method" and "Knowing the importance of environmental cleanliness", respectively.

All other items under this aspect of skills enhancement were rated as important with much benefited degree of benefits ranging from $4.47-4.25$ mean scores.

All items in entrepreneurship obtained mean scores ranging from $4.35-4.19$ and verbally interpreted as important.

Only one item had a mean score of 4.43 with verbal interpretation as important which is "Observe precautionary measures during emergency cases". The rest of the items obtained mean 
scores ranging from $4.60-4.53$ and verbally interpreted as very important with the degree of benefit as very much benefited.

In so far as values education/formation is concerned, only one item had a mean score of 4.49 and verbally interpreted as Important which was "Apply appropriate values in every undertaking". All others obtained mean scores ranging from 4.67 to 4.51 with Very Important verbal interpretation and Very much benefited degree of benefit.

4. Significant difference in the results of the benefits of NSTP-CWTS respondents as categorized as to gender.

Table 1. Difference in the Benefits of NSTP-CWTS when Respondents are Categorized as to Gender

\begin{tabular}{|c|c|c|c|c|c|c|}
\hline & MALE & FEMALE & TOTAL & $\begin{array}{c}\text { COMPUTED F- } \\
\text { VALUE } \\
\end{array}$ & $\begin{array}{c}\text { SIGNIFICANCE } \\
\text { LEVEL } \\
\end{array}$ & $\begin{array}{c}\text { VERBAL } \\
\text { INTERPRETATION } \\
\end{array}$ \\
\hline Ability to communicate & 4.63 & 4.73 & 4.70 & 3.156 & .076 & No Significance \\
\hline Better interpersonal relationship & 4.14 & 4.35 & 4.28 & 7.678 & .006 & Significant \\
\hline Ability to empathize & 3.99 & 4.01 & 4.01 & .057 & .811 & No Significance \\
\hline Ability to be a team player & 4.14 & 3.99 & 4.04 & .507 & .100 & No Significance \\
\hline Ability to prioritize others' needs & 4.20 & 4.26 & 4.24 & 13.990 & .477 & No Significance \\
\hline $\begin{array}{l}\text { Knowledge of the key roles of a } \\
\text { leader }\end{array}$ & 4.22 & 4.51 & 4.40 & 1.008 & .000 & Significant \\
\hline Ability to listen & 4.77 & 4.82 & 4.80 & 6.363 & .316 & No Significance \\
\hline Involving others decision making & 4.23 & 4.42 & 4.35 & 3.951 & .012 & Significant \\
\hline MEAN FOR BASIC LEADERSHIP & 4.29 & 4.39 & 4.35 & 3.951 & .047 & Significant \\
\hline $\begin{array}{l}\text { Awareness of the relationship } \\
\text { among physical, mental and } \\
\text { social health }\end{array}$ & 4.57 & 4.68 & 4.64 & 3.476 & .063 & No Significance \\
\hline $\begin{array}{l}\text { Better understanding of family } \\
\text { planning }\end{array}$ & 4.33 & 4.31 & 4.32 & .089 & .766 & No Significance \\
\hline $\begin{array}{l}\text { Awareness of the causes and } \\
\text { prevention of drug abuse }\end{array}$ & 4.30 & 4.43 & 4.38 & 3.312 & .069 & No Significance \\
\hline Awareness of laws on drug abuse & 4.24 & 4.35 & 4.31 & 2.155 & .143 & No Significance \\
\hline $\begin{array}{l}\text { Wider knowledge of } \\
\text { communicable diseases and their } \\
\text { preventions }\end{array}$ & 4.28 & 4.43 & 4.38 & 4.287 & .039 & Significant \\
\hline $\begin{array}{l}\text { Necessity of observing proper } \\
\text { hygiene }\end{array}$ & 4.39 & 4.64 & 4.55 & 12.940 & .000 & Significant \\
\hline 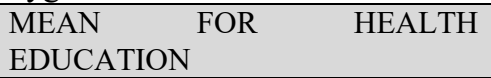 & 4.35 & 4.47 & 4.43 & 6.743 & .010 & Significant \\
\hline $\begin{array}{l}\text { Better knowledge of using leisure } \\
\text { hours productively }\end{array}$ & 4.32 & 4.41 & 4.38 & 1.537 & .216 & No Significance \\
\hline $\begin{array}{l}\text { Importance of recreation to the } \\
\text { different aspects of a person }\end{array}$ & 4.21 & 4.29 & 4.26 & 1.085 & .298 & No Significance \\
\hline $\begin{array}{l}\text { Knowledge of the kinds of } \\
\text { recreation }\end{array}$ & 4.18 & 4.23 & 4.21 & .398 & .528 & No Significance \\
\hline $\begin{array}{l}\text { Identify different recreational } \\
\text { activities appropriate for different } \\
\text { ages }\end{array}$ & 4.16 & 4.20 & 4.18 & .328 & .567 & No Significance \\
\hline $\begin{array}{l}\text { Awareness of recreation for } \\
\text { special cases }\end{array}$ & 4.17 & 4.22 & 4.20 & .415 & .520 & No Significance \\
\hline $\begin{array}{l}\text { Enhancement of social } \\
\text { skills/interaction with others }\end{array}$ & 4.42 & 4.52 & 4.48 & 1.882 & .171 & No Significance \\
\hline MEAN FOR RECREATION & 4.24 & 4.31 & 4.29 & 1.376 & .241 & No Significance \\
\hline $\begin{array}{l}\text { Better management of waste } \\
\text { materials through 3R's method } \\
\text { (reuse, reduce, recycle) }\end{array}$ & 4.67 & 4.78 & 4.74 & 4.003 & .046 & Significant \\
\hline $\begin{array}{l}\text { Knowledge of understanding } \\
\text { different plants appropriate to } \\
\text { quality and type of soil }\end{array}$ & 4.27 & 4.24 & 4.25 & .139 & .709 & No Significance \\
\hline
\end{tabular}




\begin{tabular}{|c|c|c|c|c|c|c|}
\hline $\begin{array}{l}\text { Knowing the importance of } \\
\text { environment cleanliness }\end{array}$ & 4.60 & 4.72 & 4.68 & 4.882 & .028 & Significant \\
\hline $\begin{array}{llrl}\text { Better } & \text { knowledge } & \text { of } & \text { our } \\
\text { country's natural resources } & \\
\end{array}$ & 4.39 & 4.42 & 4.41 & .329 & .567 & No Significance \\
\hline $\begin{array}{l}\text { Ability to understand human } \\
\text { interference with ecosystem }\end{array}$ & 4.37 & 4.39 & 4.38 & .119 & .730 & No Significance \\
\hline $\begin{array}{l}\text { Ability to identify the causes of } \\
\text { ecological imbalance and ways to } \\
\text { achieve ecological balance }\end{array}$ & 4.34 & 4.38 & 4.37 & .357 & .550 & No Significance \\
\hline $\begin{array}{l}\text { MEAN FOR ENVIRONMENTAL } \\
\text { RESOURCE MANAGEMENT }\end{array}$ & 4.44 & 4.49 & 4.47 & 1.121 & .290 & No Significance \\
\hline $\begin{array}{l}\text { Better understanding of } \\
\text { entrepreneurship }\end{array}$ & 4.28 & 4.38 & 4.34 & 1.378 & .241 & No Significance \\
\hline $\begin{array}{l}\text { Roles of an entrepreneur in our } \\
\text { society }\end{array}$ & 4.18 & 4.24 & 4.21 & .598 & .440 & No Significance \\
\hline $\begin{array}{l}\text { Advantages and disadvantages of } \\
\text { the different forms of business }\end{array}$ & 4.18 & 4.28 & 4.24 & 1.897 & .169 & No Significance \\
\hline $\begin{array}{l}\text { Requirements of organizing a } \\
\text { business }\end{array}$ & 4.14 & 4.22 & 4.19 & 1.097 & .296 & No Significance \\
\hline $\begin{array}{l}\text { Learning simple techniques of } \\
\text { doing small business }\end{array}$ & 4.18 & 4.32 & 4.27 & 3.062 & .081 & No Significance \\
\hline $\begin{array}{l}\text { Better knowledge of the } \\
\text { importance of livelihood projects } \\
\text { to a person's economic progress }\end{array}$ & 4.26 & 4.36 & 4.33 & 1.448 & .230 & No Significance \\
\hline $\begin{array}{ll}\text { MEAN } & \text { FOR } \\
\text { ENTREPRENEURSHIP } & \\
\end{array}$ & 4.20 & 4.30 & 4.26 & 2.387 & .123 & No Significance \\
\hline $\begin{array}{lll}\begin{array}{l}\text { Identify } \\
\text { cases }\end{array} & \text { different } & \text { emergency } \\
\end{array}$ & 4.61 & 4.60 & 4.60 & .001 & .973 & No Significance \\
\hline $\begin{array}{lr}\text { Identify and apply } & \text { survival } \\
\text { techniques/procedure } & \text { during } \\
\text { emergency cases } & \\
\end{array}$ & 4.46 & 4.58 & 4.53 & 3.485 & .063 & No Significance \\
\hline $\begin{array}{l}\text { Observe precautionary measures } \\
\text { during emergency cases }\end{array}$ & 4.38 & 4.46 & 4.43 & 1.429 & .233 & No Significance \\
\hline $\begin{array}{l}\text { Ability to practice different } \\
\text { techniques in First Aid }\end{array}$ & 4.49 & 4.59 & 4.55 & 1.854 & .174 & No Significance \\
\hline $\begin{array}{l}\text { MEAN FOR FIRST AID AND } \\
\text { EMERGENCY }\end{array}$ & 4.48 & 4.56 & 4.53 & 1.792 & .181 & No Significance \\
\hline Identify different Filipino values & 4.59 & 4.66 & 4.64 & 1.443 & .230 & No Significance \\
\hline Understand these Filipino values & 4.54 & 4.64 & 4.61 & 3.373 & .067 & No Significance \\
\hline $\begin{array}{lrl}\text { Apply appropriate } & \text { values in } \\
\text { every understanding } & & \\
\end{array}$ & 4.48 & 4.50 & 4.50 & .120 & .730 & No Significance \\
\hline $\begin{array}{l}\text { Better understanding of the 4M's } \\
\text { of Good Citizen (Maka-Diyos, } \\
\text { Maka-Tao, Maka-Bayan, Maka- } \\
\text { Kalikasan) }\end{array}$ & 4.59 & 4.67 & 4.64 & 1.436 & .231 & No Significance \\
\hline $\begin{array}{ll}\text { Bettter understanding } & \text { of } \\
\text { nationalism and patriotism } & \\
\end{array}$ & 4.39 & 4.58 & 4.51 & 7.307 & .007 & Significant \\
\hline $\begin{array}{l}\text { Actual practice in daily life } \\
\text { modern Filipino values (faith, } \\
\text { loyalty, caring and affection, } \\
\text { industry and endurance) } \\
\text { Pananalig, Katapatan, Pag- } \\
\text { aaruga, Kasipagan, Tibay ng } \\
\text { Loob) }\end{array}$ & 4.61 & 4.71 & 4.67 & 2.527 & .113 & No Significance \\
\hline $\begin{array}{lcc}\text { MEAN } & \text { FOR } & \text { VALUES } \\
\text { EDUCATION/FORMATION }\end{array}$ & 4.53 & 4.63 & 4.59 & 3.848 & .050 & Significant \\
\hline
\end{tabular}

Table 1 reveals that there is a significant difference when respondents are categorized as to gender on the aspects: Basic Leadership, Health education and Values Education as enhanced by the computed values of $3.951 ; 6.743$ and 3.848 respectively. These findings indicate that females benefited more than their male counterparts from the above-mentioned aspects. NSTP-CWTS helped enhanced the female implementers' ability to communicate, ability to listen and 
interpersonal relationship. It also made them very much aware of the importance of health education and applies in their daily life good values. Thus, the hypothesis is rejected in so far as these aspects are concerned.

On the other hand, there was no significant difference between males and females on the aspects of Recreation, Environmental Resource Management, Entrepreneurship and First Aid and Emergency with computed values ranging from 1.121 to 2.387 . Thus, the hypothesis is accepted.

\section{Conclusion}

In the light of the foregoing findings of the study, the following conclusions are drawn: NSTP-CWTS implementers are predominantly female. Majority of the respondents come from the College of Business and Entrepreneurial Technology;

The respondent-implementers derived benefits from skills enhancement in all its items particularly: Ability to Communicate; Ability to Listen and Involving others in Decision-making; Awareness of the Relationship among Physical, Mental and Social Health; Necessity of Observing Proper Hygiene; Enhancement of Social Skills/Interaction with Others; Better Management of Waste Materials through 3R's Method; Knowing the Importance of Environmental Cleanliness; Better Knowledge of the Importance of Livelihood Projects to a Person's Economic Progress and Ability to Practice Different Techniques in First Aid.

In so far as values education/formation is concerned, the respondents have "Better Understanding of the 4M's of Good Citizen" Benefits derived from skills enhancement are generally rated Important while those of values education/formation are rated Very Important. Generally, the respondents benefited very much in the NSTP-CWTS implementation regardless of the college they belonged to. When categorized as to gender, female implementers benefited more on basic leadership, health education and values formation. The outstanding problems/difficulties encountered in the NSTP-CWTS implementation are related to budgetary allocation and inadequacy of funds. The implementation of NSTP-CWTS necessitate collection of fees from the students for materials and equipment and periodic trainings for faculty development but lack of administrative support and proper allocation of NSTP funds for that purpose affected the degree of success and effectiveness of the program especially during community immersion as implementers have to rely on their own resources and initiatives.

Based on the conclusions of the study, the following recommendations are forwarded: For some aspects of NSTP-CWTS rated Very Important by implementers, faculty members handling classes need to exert efforts to maintain the same level of assessment; For some aspects of NSTPCWTS rated Important, there is a need to further improve training strategies to raise the level of implementers' assessment; Since NSTP-CWTS was implemented in 2002, a review of its curriculum content is recommended to make it more relevant to the present time; The RTU administrators together with the Office of NSTP need to look into the passive attitude of local government officials and NGO's towards NSTP to ensure that both clienteles and implementers benefit from any project undertaken; The administration need to support the programs of NSTP by allocating adequate budget for materials and equipment as well as periodic trainings of its faculty as the success and sustainability of the NSTP implementation are reflective of how well the program is supported and aptly given funds. Further research may be undertaken to improve the implementation of NSTP and to achieve the goals for which it was mandated.

\section{References}

[1] Isabel Panopio et al., General Sociology, Quezon City, Philippines, 2004.

[2] Herculano V. Sabas, Readings in the Civic Welfare Training Service, Manila, 2002.

[3] F.E. Fiedler, A Theory of Leadership Effectiveness, New York, McGrew-Hill,1967.

[4] H.Koontz, C. O’Donnell, Principles of Management, New York, McGrew-Hill, 1981. 
[5] GR. Terry, S.Franklin, Principles of Management. Homewood, Ill: Irwin, 1982.

[6] F. Fajardo, Entrepreneurship. National Bookstore, Valenzuela, Philippines, 1994.

[7] T. Coloma, M. Herrera, Towards a Relevant and Responsive National Service Training Program in the Schools: Focus on Community Organization and Development, Mutya Publishing House, Quezon City, 2004.

[8] EA. Liberal et al., Introduction to Entrepreneurship, $2^{\text {nd }}$ Revised ed., Small Enterprises Research and Development Foundation, Inc., 2007.

[9] M. Quendangan et al., National Service Training Program, Civic Welfare Training Service, Jimczyville Publications, Philippines, 2012.

[10] M. Quendangan et al., NSTP-CWTS Worktext, Trinitas Publishing, Quezon City Philippines, 2011. 